\title{
Relationship Of Knowledge And Attitude Toward Prevention Of HIV And AIDS Behavior At Cafe Pramusaji In Tanjung Bira
}

\author{
Andi Suswani ${ }^{*}$, Irfanita Nurhidayah², Wiwis Lestari ${ }^{3}$ \\ Departemen Community and Family Nursing, Stikes Panrita Husada Bulukumba, Indonesia ${ }^{1}$ \\ Departemen Surgical and Medical Nursing , Stikes Panrita Husada Bulukumba ,Indonesia ${ }^{2}$ \\ S1 Nursing Study Program, Stikes Panrita Husada Bulukumba, Indonesia ${ }^{3}$
}

\author{
Corresponding Autor : Aderialmakmur@yahoo.co.id**
}

\begin{abstract}
AIDS or Acquired Immuno Deficiency Syndrome is a collection of symptoms that arise due to decreased immunity caused by infection by HIV. As a result of decreased immunity, the person is very susceptible to various infectious diseases that are often fatal. With a healthy lifestyle, the time between HIV infection and becoming ill with AIDS can range from 10-15 years, sometimes even longer. Not having sexual intercourse with an infected person, especially anal intercourse, ie body fluids, blood, semen or vaginal secretions most likely to be exchanged, is the only $100 \%$ effective way to prevent HIV transmission through sex. The purpose of this study is to determine the relationship of knowledge, attitudes with HIV and AIDS prevention behavior in Cafe Waiters in Tanjung Bira, Bontobahari District, Bulukumba Regency. This study uses an analytic observational design with a "cross-sectional" approach. The study population was all cafe waitresses, amounting to 150 waitresses. The number of samples was 59 respondents. The sampling technique uses probability sampling with a systematic sampling approach. Data collection using a questionnaire. The analysis used the chi-square alt merge cell test and chisquare alt fisher test. The results showed that there was a relationship between knowledge and HIV and AIDS prevention behavior in Cafe Waiters in Tanjung Bira, Bontobahari District, Bulukumba Regency, as evidenced by $\rho=0.038<\alpha=0.05$ and there was a relationship between attitudes and HIV and AIDS prevention behaviors in Cafe stewards in Tanjung Bira, Bontobahari District, Bulukumba Regency, proven by $\rho=0.017<\alpha=0.05$. The conclusion in this study is that there is a relationship between knowledge and attitudes with HIV and AIDS prevention behavior in Cafe Waiters in Tanjung Bira, Bontobahari District, Bulukumba Regency.
\end{abstract}

Keywords: HIV and AIDS, Knowledge, Attitudes, Behavior, Female Sexual Workers

\section{INTRODUCTION}

According to Haringi, et al (2016) The burden of disease in developing countries is currently increasing. This has been shown from various studies where this has become a public health problem. HIV (Human Immunodeficiency Virus) and AIDS (Acquired Immunodeficiency Virus) are new challenges faced by patients and the global health system. Where, the HIV and AIDS epidemic is still a major problem for people in developing countries. WHO and UNAIDS estimate that more than 35.3 million people are infected with HIV worldwide, and $90 \%$ of them are in developing countries. Based on 


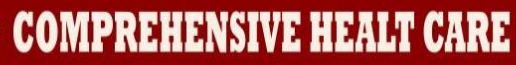

data trends in the National AIDS Commission, it is predicted that in 2015 there will be an increase in cases to 924,000 cases with a prevalence of $0.49 \%$. This figure jumped sharply to $2,117,000$ cases in 2015 with a prevalence of $1.00 \%$. Central Disease Control and Prevention (CDC) reports that the incidence of HIV in adolescents aged 13-24 years increased by $22 \%$ from 2010 (Haringi, et al, 2016).

HIV and AIDS that occur in Indonesia itself also increases every year, as evidenced by the number of cases of HIV and AIDS in Indonesia in 2011 if a total of 28,343, increased to 30,258 in 2012, then in 2013 increased to 35,303 with a mortality rate of 726 soul. Meanwhile, the cumulative number of HIV and AIDS cases according to the second largest age group, occurred in the age range of 20-29 years by 18,287 people and 30-39 years of age by 15,816 people (Ditjen PP and PL Ministry of Health Republic of Indonesia, 2014). The increase in HIV and AIDS cases that occur shows that HIV and AIDS has become a problem that is at the center of people's lives. HIV and AIDS cases have occurred in various provinces in Indonesia. In 2014, the most widespread distribution of HIV and AIDS cases occurred in DKI Jakarta, East Java and Papua. Cases of HIV and AIDS that have occurred and spread throughout Indonesia as many as 198,573 cases (Ameilia, 2015). Based on the collection of health profile data in 2014 the number of HIV cases was 874 cases, AIDS was 687 cases, AIDS-related deaths were 425 cases consisting of 351 cases of men and 74 cases of women (South Sulawesi Health Office, 2014). Data from the Bulukumba District Health Office was found on the prevalence of HIV and AIDS from 2006-2016 with HIV and AIDS, as many as 169 people (Health Office, 2016).

One of the high risks of being exposed to HIV and AIDS is the Sexual Worker Women (FSW) and the mode of transmission through sexual contact. A Female Sexual Worker (WPS) is a woman who has sex with a person of the opposite sex outside of the legal marriages with the intention of obtaining sexual satisfaction or material benefits for herself or others and is inseparable from the behavior of changing partners (Pertiwi, et al , 2014). The things that underlie WPS go into the world of prostitution for various reasons, one of which is economic factors and personal problems. One of the easy job options for women with low skills and education, but with the hope of getting a decent life is by undergoing a profession as a Sexual Worker Woman (WPS) (Regar, Kairupan, 2016). The number of female sex workers (WPS) who are prone to contracting HIV and AIDS in Indonesia is 108,043 people while in the area of South Sulawesi Province is 


\section{COMPRABHANSWE HABH CARE}

1692 people. Up to April 2012, there were 76 people in Bulukumba who became waitresses and those who tested positive for HIV through Voluntary Counseling and Testing (VCT) as many as 8 people (Fadhali, et al, 2012). In 2017 the results of observations, researchers said that there was an increase of 150 people who became waitresses, where in the waitress community there were WPS. To prevent the occurrence or transmission of HIV and AIDS ie not having sexual relations with an infected person is the only $100 \%$ effective way to prevent HIV transmission through sex. Condoms can reduce the risk of transmission, but do not eliminate the possibility of transmission altogether and avoid injection drug use.

\section{MATERIAL AND METHODS}

This type of research is an observational analytic study with a "cross sectional" approach where data concerning independent and dependent variables are collected at the same time (Dharma, 2011). Sampling in this study was done by probablility sampling technique is sampling that provides the same opportunity or opportunity for each individual in the population to become a research sample, using a systematic sampling approach (Dharma, 2011). In this study the population is all women who work as waitresses who are in 17 Cafe in Tanjung Bira, District Bontobahari, Bulukumba Regency, amounting to 150 people. The sample in this study amounted to 59 people. The research instrument was a questionnaire sheet in structured statements to identify the Relationship between Knowledge and Attitudes with HIV and AIDS Prevention Behavior in Cafe Waiters in Tanjung Bira, Bontobahari Subdistrict, Bulukumba Regency which will be tested for validity and reliability. The statistical test used in knowledge with behavior using the Chi-Square test by using alternative Merge Cell while in the attitude with the behavior using the Chi-Square test if it meets the requirements but if it does not meet the alternative Fisher is used. This test aims to see whether or not there are differences in proportions which means that the frequency distribution observed is expected with a significance level of 0.05 . If P-Value $<0.05$ means there is a significant relationship (Ho is rejected) while P-Value $>0.05$ means there is no meaningful relationship (Ho is accepted). 


\section{COMPRABHENSWE HEAH CARE}

RESULTS

Table 1. Distribution of the number of respondents based on the characteristics of the waitress

\begin{tabular}{lcc}
\hline Age & $\mathbf{n}$ & Percentage (\%) \\
\hline 17-21 Year & 18 & 30,5 \\
22-26 Year & 16 & 27,1 \\
27-31 Year & 8 & 13,6 \\
32-36 Year & 10 & 16,9 \\
37-41 Year & 5 & 8,5 \\
42-46 Year & 2 & 3,4 \\
\hline Level Of Education & $\mathbf{n}$ & Percentage (\%) \\
\hline Basic & 14 & 23,7 \\
Middle & 23 & 39,0 \\
High & 22 & 37,3 \\
\hline Amount & $\mathbf{5 9}$ & $\mathbf{1 0 0}$ \\
\hline
\end{tabular}

Table 1 above explained that the most respondents were respondents aged 17-21 years as many as 18 people with a percentage (30.5\%) and the least respondents were respondents with ages 42-46 years as many as 2 people with a percentage (3.4\%). Based on the most recent education, most respondents were respondents with a junior high school education of 23 people with a percentage (39\%) and respondents with the least education were elementary school as many as 14 people with a percentage (23.7\%).

Table 2 Frequency Distribution of Cafe Waiters' Knowledge in Tanjung Bira

\begin{tabular}{lcc}
\hline Knowledge & $\mathbf{n}$ & Percentage (\%) \\
\hline Good & 36 & 61,0 \\
Enough & 16 & 27,1 \\
less & 7 & 11,9 \\
\hline Amount & $\mathbf{5 9}$ & $\mathbf{1 0 0 , 0}$ \\
\hline
\end{tabular}

Table 2 above, more than half of the respondents had knowledge of café waitresses about HIV and AIDS prevention who had good knowledge of 36 (61.0\%), sufficient knowledge of 16 (27.1\%), while cafe waitress knowledge of HIV and AIDS prevention was less, namely 7 (11.9\%).

Table 3. Distribution of Frequency Attitudes of Cafe Waiters in Tanjung Bira,

\begin{tabular}{lcc}
\hline Attitude & $\mathbf{n}$ & Percentage (\%) \\
\hline Positif & 43 & 72,9 \\
Negatif & 16 & 27,1 \\
\hline Amount & $\mathbf{5 9}$ & $\mathbf{1 0 0 , 0}$ \\
\hline
\end{tabular}

Table 3 above, more than half of the respondents had positive cafe waitress attitudes about HIV and AIDS prevention, 43 (72.9\%), while those who had negative attitudes were 16 or (27.1\%). 


\section{COMPRABHENSWE HEAH CARE}

Table 4 Frequency Distribution of Cafe Waiters' Behavior in Tanjung Bira, Bontobahari District

\begin{tabular}{lcc}
\hline Behavior & n & Percentage (\%) \\
\hline Good & 26 & 44,1 \\
Not Good & 33 & 55,9 \\
\hline Amount & $\mathbf{5 9}$ & $\mathbf{1 0 0 , 0}$ \\
\hline
\end{tabular}

Table 4 above more than some of the respondents had cafe waitress behavior about HIV and AIDS prevention, more than some respondents had good behavior, 26 (44.1\%), while respondents who had bad behavior were 33 or (55.9\%).

Table 5. Analysis of Relationship between Knowledge and HIV and AIDS Prevention Behavior

\begin{tabular}{|c|c|c|c|c|c|c|c|}
\hline \multirow{3}{*}{ Knowledge } & \multicolumn{4}{|c|}{ Behavior } & & & $P$ \\
\hline & & od & & Good & \multicolumn{2}{|c|}{ Amount } & \\
\hline & $\mathrm{n}$ & $\%$ & $\mathrm{n}$ & $\%$ & $\mathrm{n}$ & $\%$ & \\
\hline Good & 12 & 46,15 & 24 & 72,72 & 36 & 61,01 & \multirow{2}{*}{$0,038^{*}$} \\
\hline Not Good & 14 & 53,84 & 9 & 27,27 & 23 & 38,98 & \\
\hline Amount & 26 & 100 & 33 & 100 & 59 & 100 & \\
\hline
\end{tabular}

Based on table 5 above, it can be seen that respondents' perceptions of good knowledge with good behavior are 12 respondents (46.15\%), the category of knowledge is sufficient and less with good behavior as many as 14 respondents (53.84\%), the category of good knowledge with good behavior good as many as 24 respondents (72.72\%), enough knowledge category with bad behavior as many as 9 respondents (27.27\%). Based on the results of the analysis using the chi square statistical test obtained value of $\rho=0.001<\alpha=0.05$. However, after being interpreted, it turns out that there are 2 cells (33.3\%) that have an excepted count value of less than 5 . Based on this, the author then performs an alternative test that is to do a cell merge test and the value $\rho=0.038<\alpha=0.05$. Based on these results it can be concluded that there is a relationship of knowledge with HIV and AIDS prevention behaviors in cafe waitresses in Tanjung Bira, Bontobahari District, Bulukumba Regency.

Table 6. Analysis of the Relationship between Attitudes and Behavior in Prevention of HIV and AIDS in Waiters

\begin{tabular}{|c|c|c|c|c|c|c|c|}
\hline \multirow{3}{*}{ Attitude } & \multicolumn{6}{|c|}{ Behavior } & \multirow{3}{*}{$P$} \\
\hline & \multicolumn{2}{|c|}{ Good } & \multicolumn{2}{|c|}{ Not Good } & \multicolumn{2}{|c|}{ Amount } & \\
\hline & $\mathbf{n}$ & $\%$ & $\mathrm{n}$ & $\%$ & $\mathrm{n}$ & $\%$ & \\
\hline Positif & 23 & 88,46 & 20 & 60,60 & 43 & 72,88 & \\
\hline Negatif & 3 & 11,53 & 13 & 39,39 & 16 & 27,11 & $0,017^{*}$ \\
\hline Amount & 26 & 100 & 33 & 100 & 59 & 100 & \\
\hline
\end{tabular}

Based on table 6 above, it can be seen that respondents' perceptions about positive attitudes with good behavior are 23 respondents (88.46\%), negative attitude categories 


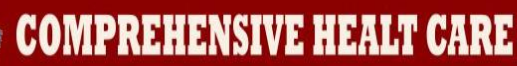

with good behavior are 3 respondents (11.53\%), positive attitude categories with bad behavior as much as 20 respondents (60.60\%), negative attitude categories with bad behavior as many as 13 respondents (39.39\%). Based on the analysis using the chi square statistical test obtained value $\rho=0.017<\alpha=0.05$. Based on these final results it can be concluded that there is a relationship between attitudes and HIV and AIDS prevention behaviors in cafe waitresses in Tanjung Bira, Bontobahari District, Bulukumba Regency.

\section{DISCUSSION}

In the bivariate analysis results obtained good knowledge with good behavior as many as 12 respondents (46.15\%), the category of knowledge enough with good behavior as many as 14 respondents (53.84\%), the category of good knowledge with bad behavior as many as 24 respondents (72, 72\%), the category of sufficient knowledge with bad behavior as many as 9 respondents (27.27\%). From these results it can be seen that there are still 24 respondents whose behavior is not good despite good knowledge, but this does not affect the results of the study because 14 respondents enough knowledge still has good behavior.

The results of the study are not in line with the study of Fadhali, et al, 2012 who said that the waitresses did good prevention practices more than those who had high knowledge compared to those who had low knowledge. This means that the higher the knowledge of the waiter the better the prevention of HIV and AIDS transmission, and the lower the knowledge of the waiter, the lower the prevention, where the statistical test results obtained $\mathrm{p}=0.002(\mathrm{p}>0.05)$. This means there is a link between knowledge and preventive practice.

From the results of Setyowati's research, 2015 is in line with Fadhali's study, 2012 in which the results of the study of well-informed respondents tend to use condoms during sexual transactions. While knowledgeable respondents were less likely not to use condoms during sexual transactions, where the statistical test results obtained a value of $\mathrm{p}=0.001(\mathrm{p}>0.05)$. This means there is a relationship of knowledge with the practice of using condoms.

Researchers assume that apart from good knowledge, self awareness must be needed so that behavior is also good in preventing HIV and AIDS. With the awareness within the waiter himself is able to behave well in the prevention of HIV and AIDS, but sometimes there are also several factors why the waiter does not prevent HIV and AIDS, 


\section{COMPRAHENSWE HEAH GARE}

one of which is the characteristics of customers who not all customers want to use contraception (condoms) when doing sexual relations and characteristics of the cafe owner who has several conditions in the place, one of which does not use contraception (condoms). Here are some reasons why waiters do not behave properly about HIV and AIDS prevention, even though they already know a lot about what HIV and AIDS is, as evidenced by the frequency results about respondents' knowledge. In the bivariate analysis results obtained positive attitude categories with good behavior 23 respondents (88.46\%), negative attitude categories with good behavior 3 respondents (11.53\%), positive attitude categories with bad behavior 20 respondents $(60.60 \%)$, negative attitude categories with bad behavior 13 respondents (39.39\%). From these results it can be seen that there are still 20 respondents whose behavior is not good but their attitude is positive, but this does not affect the results of the study because 23 respondents who have a positive attitude have good behavior.

This study is in line with research conducted by Haerana and Muslimah, 2015. Said that the GWL community who had more negative attitudes were not good at preventing HIV and AIDS, whereas the GWL community who had more positive attitude were better at doing prevention. The results of the bivariate analysis showed that there was a relationship $(\mathrm{p}$ value $=0.015)$ between attitudes and HIV and AIDS prevention behavior in the Jambi City GWL community.

Research Raynera, et al, 2013, said that respondents who have a positive attitude with positive behavior will tend to be successful in relation to the prevention of STIs. And in this study it was found that a positive attitude will also make positive behavior from someone, from the chi square test results obtained $\rho$ value of $0.001 \leq 0.05$, it can be concluded that there is a relationship between attitudes with the behavior of CSWs about STI prevention .

The researcher assumes that a positive attitude should give or do good behavior, seen from a positive attitude and still doing bad behavior, this is usually due to the lack of readiness in the respondent to behave well, in preventing HIV and AIDS, this is also influenced because lack of guidance and support from family and peers. Even attitudes with HIV and AIDS prevention behavior are influenced by economic factors, where a waitress is already good at behaving (positively) about preventing HIV and AIDS, but because of economic factors the waitress does not perform good behavior in preventing HIV and AIDS, where a waitress must obey what is said by the customer and what is said 


\section{COMPRABHENSWE HEAH CARE}

by the owner of the cafe. Some customers when they want to have sexual intercourse, do not want to use contraception (condoms) this results in the waiter doing negative behavior because they do not use contraception (condoms) when having sexual intercourse, even though the respondent already has a positive attitude in HIV and AIDS prevention but because economic matters respondents did not pay attention about the negative behavior that they do. For respondents who have negative attitudes but have positive behaviors, this is due to environmental factors and their fellow professionals who show and inform that positive behavior regarding the prevention of sexually transmitted diseases, especially in HIV and AIDS is very important. One of the prevention of sexually transmitted diseases is to use contraception (condoms) when having sexual intercourse and not having sexual intercourse.

\section{CONCLUSIONS}

There is a relationship between attitudes with HIV and AIDS prevention behavior in Cafe Waiters in Tanjung Bira, Bontobahari District, Bulukumba Regency. So that this research can provide information about the relationship between knowledge and attitudes with HIV and AIDS prevention behaviors in Cafe Waiters in Tanjung Bira, Bontobahari District, Bulukumba Regency.

\section{REFERENCES}

Ameilia, Y. (2015), Menyibak Ketabuan : Sebuah Tinjauan Atas Social Marketing Program Pencegahan HIV-AIDS Di Indonesia: Jurnal Studi Manajemen, Vol. 9, No 1, April 2015.

Akhiat. (2016), Hubungan Tingkat Pendidikan Dengan Pengetahuan Pekerja Seks Komersial Tentang Penyakit HIV/AIDS Di Lokalisasi Teluk Bayur : Jurnal Kesehatan, Vol VII, No 1, April 2016, Hal 156-160

Dharma, Kelana Kusuma. (2011). Metodologi penelitian keperawatan. TIM : Jakarta Timur.

Dinas Kesehatan Provinsi Sulawesi Selatan (2015). Profil Kesehatan Provinsi Sulawesi Selatan 2014-2015, Dinas Kesehatan Provinsi Sulawesi Selatan, Makassar.

Fadhali, A., et al (2012), Faktor Yang Berhubungan Dengan Pencegahan HIV Dan AIDS Di Kalangan Pramusaji Kafe Di Tanjung Bira Kabupaten Bulukumba: Jurnal.

Haringi, S., et al (2016), Gambaran Perilaku Siswa SMA Dalam Upaya Pencegahan HIV/AIDS Di Wilayah Kota Kendari : Jurnal.

Haerana, Bs.T \& Muslimah. (2015), Hubungan Pengetahuan, Sikap, Motivasi Dan Peran Petugas LSM Terhadap Perilaku Pencegahan HIV/AIDS Pada Komunitas GWL Jambi : Jurnal Kesehatan Masyarakat, Vol.1, No.2, Agustus 2015.

Hidayat, Andi Aziz Alimul. (2014), Metode penelitian keperawatan dan teknik analisa data. Salemba Medika : Jakarta. 


\section{COMPRABHENSWE HEAH CARE}

Jalaluddin. (2013), Filsafat ilmu pengetahuan. Cetakan 1. PT Raja Grafindo Persada : Jakarta.

KNEPK. (2012). Etika penelitian

Lestari, Titik. (2015), Kumpulan teori untuk kajian pustaka penelitian kesehatan. Cetakan 1. Nuha Medika : Jl. Sadewa No. 1 Sorowajan Baru, Yogyakarta.

Munarni, R. (2016). Sosialisasi Pencegahan Infeksi Menular Seksual (IMS) Di Lokalisasi Bati 15 Oleh Komisi Penanggulangan AIDS (KPA) Kota Tanjung Pinang : Skripsi tidak diterbitkan.

Notoadmodjo, Soekidjo. (2014). IImu perilaku kesehatan, Cetakan 2. PT Rineka Cipta : Jakarta.

Nurarif, AH., Kusuma, H. (2015), Aplikasi asuhan keperawatan berdasarkan diagnosa medis dan nanda nic-noc, Edisi revis jilid 1. Mediaction Jogja : Jogjakarta.

Pertiwi, M.R., et al. (2014). Hubungan Antara Penggunaan Kondom Dengan Kejadian Penyakit Menular Seksual Di Wilayah Puskesmas Duren Kecematan Bandung Kabupaten Semarang: Jurnal

Raynera, C., et al. (2013). Sikap Dengan Perilaku Pekerja Seks Komersial (PSK) Tentang Pencegahan Infeksi Menular Seksual : Jurnal

Regar, P.M \& Kairupan, J.K. (2016). Pengetahuan Pekerja Seks Komersial (PSK) Dalam Mencegah Penyakit Kelamin Di Kota Manado : Jurnal Holistik, Tahun IX No. 17/ Januari - Juni 2016.

Restianti, Hetti. (2009). Memahami penyakit menular seksual (PMS), PT Puri Pustaka : Bandung.

Setyowati, T., et al. (2015). Faktor-faktor Berhubungan dengan Praktik Penggunaan Kondom pada Kelompok Risiko Tinggi (Wanita Pekerja Karaoke dan Café) dalam Pencegahan Penyakit Menular Seksual (PMS) : Jurnal

Sugiyono. (2012). Statika untuk penelitian. ALFABETA : Bandung.

Sujarweni, W. (2014). Metodologi penelitian keperawatan. Gafa media : Yogyakarta.

Syamsuddin., et al. (2015). Pedoman praktis metodologi penelitian internal. WADE GROUP : Indonesia.

Wawan, A., \& M, D. (2012). Teori dan pengukuran pengetahuan, sikap dan perilaku manusia. Nuhamedika : Yogyakarta. 